\title{
COVID-19 Awareness of the Optician Students
}

\author{
Optisyenlik Öğrencilerinin Covid-19 Farkındalığı

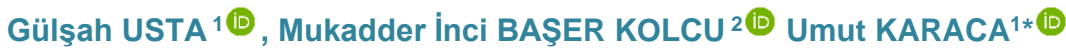

${ }^{1}$ Süleyman Demirel Üniversitesi, Tıp Fakültesi, Göz Hastalıkları AD, Isparta, Türkiye

²üleyman Demirel Üniversitesi, Tıp Fakültesi, Tıp Eğitimi ve Bilişimi AD , Isparta, Türkiye

\begin{abstract}
Objective: The aim of this study was to determine optician students' level of COVID-19 awareness and their attitude toward the use of personal protective equipment.

Material - Method: A cross-sectional study was conducted with a research population that consisted of Isparta University of Applied Sciences, Technical Sciences Vocational School, Department of Opticians students, who voluntarily participated in the study $(n=76)$. The questionnaire contained three parts (35 questions): demographic data (5 questions), awareness of COVID-19 (15 questions), and the transmission and prevention of COVID-19 infections at the workplace (15 questions).
\end{abstract}

Results: A total of 76 students, $67.1 \%$ of whom were women, were included in the survey. In the COVID-19 awareness part of the survey, $82.9 \%$ of the respondents reported that they knew about COVID-19, and $19.7 \%$ of them defined that this infection did not cause conjunctivitis. Regarding frames, $44.7 \%$ of the respondents stated that they would avoid frame fitting during the pandemic, and $96.1 \%$ plan to disinfect them after they have been tried on by customers.

Conclusion: The level of knowledge and awareness about this disease should not be compromised. The scope of our study revealed both that there is no training on this subject and the need for that training.

Keywords:COVID-19, awareness level, personal protective equipment, optician

Alınış / Received: 11.07..2021 Kabul / Accepted: 07.09.2021 Online Yayınlanma / Published Online: 20.12.2021 


\title{
$\operatorname{sen} 2020$
}

\begin{abstract}
ÖZET
Amaç: Çalışmamızın amacı, optisyenlik öğrencilerinin COVID-19 farkındalık düzeylerini belirlemek ve COVID-19 tedbirleri kapsamında kişisel koruyucu ekipman kullanımı hakkında düşüncelerini değerlendirmektir.

Materyal - Metod: Çalışma kesitsel tanımlayıcı tiptedir. Araştırmanın örneklemini Isparta Uygulamalı Bilimler Üniversitesi Teknik Bilimler Meslek Yüksek Okulu Optisyenlik Bölüm öğrencilerinden araştırmaya gönüllü katılan 76 öğrenci oluşturmaktadır. Veri toplama amacıyla oluşturulan anket online yazılım aracılığıyla (Google Docs) katılımcılara ulaştırımıştır. Anket formu; üç bölümden (35 soru) oluşmaktadır; demografik veriler (5 soru), COVID19 farkındalık (15 soru), işyeri ortamında COVID-19 bulaş ve korunma önlemleri (15 soru). Korunma önlemleri gözlük çerçevesi (yakın mesafe kısa süre) ve kontakt lens (yakın mesafe uzun süre) olmak üzere 2 alt kategoride değerlendirilmiştir.
\end{abstract}

Bulgular: Ankete \%67,1'i kadın 76 öğrenci katılmıştır. COVID-19 farkındalık bölümünde öğrencilerin \%82,9'u COVID-19'un hakkında bilgi sahibi olduğunu, \%19,7'si bu enfeksiyonun konjonktivit yapmadığını bildirmiştir. Katılımcıların \%44,7'si pandemi süresince gözlük çerçevesi denemesi yapmayacağını bildirirken, yapacağını ifade edenlerin \%96,1'i denenen çerçeveleri dezenfekte edeceğini bildirmiştir. Gözlük çerçevesi denetirken katılımcılardan \%77,6'sı maskeyi, \%71,1'i eldiveni, \%30,3'ü yüz siperini, \%25’i koruyucu gözlüğü kişisel koruma ekipmanları (KKE) olarak kullanacağını bildirmiştir.

Sonuç: COVID-19 hayatı tehdit eden bir enfeksiyondur. Bu hastalıkla ilgili bilgi/farkındalık düzeyinden taviz verilememelidir. Çalışmamız optisyenlik eğitiminde konu ile ilgili eksikliği ve eğitim ihtiyacını ortaya koymuştur.

\section{Introduction}

With every passing year, China has the largest human migration in the world [1]. However, this year, it made its name as the center of a serious virus migration. In December 2019, after examining samples taken from patients with pneumonia symptoms in Wuhan, China, this new virus, which was determined to be from the coronavirus family, was named coronavirus 2019 (SARS-CoV-2 or COVID-19) [2].

Studies on the transmission route of COVID-19 are ongoing. In the light of the scientific findings, it has been reported that it started as a zoonotic infection from animal to human and was then rapidly transmitted through direct contact and/or droplets from person-to-person [3]. Virus isolation was additionally shown on mucosal surfaces with direct contact, such as the mouth, nose, and eyes; it was also reported that hand contact to these infected surfaces and close distance between people in transmission by droplet are the most important risk factors [4]. In January 2020, the World Health Organization assessed this virus, which caused a pandemic with symptoms of pneumonia, as an alarming emergency public health problem for the general population [2].

Healthcare workers, especially ophthalmologists, ophthalmology nurses, and opticians who work in close proximity with and have contact with COVID-19 infected patients during the pandemic, have been reported to have high transmission potential [5]. During this period, updated recommendations have been published regularly to emphasize the importance of using personal protective equipment by increasing the awareness of opticians on COVID-19, which is an important step in the patient flow in ophthalmology [6-9]. 
The aim of our study was to determine the COVID-19 awareness level of opticians and to evaluate their opinions regarding the personal protection measures that they want to use in their professional lives.

\section{Material and Method}

The study was conducted with the approval of Süleyman Demirel University Clinical Research Ethics Committee (17.11.2020/359) and the permission of the Ministry of Health Scientific Research Platform (transaction no. 2020-10-06T15_43_17.xml), in accordance with the principles of the Declaration of Helsinki. Informed consent forms were obtained from the participants.

The study design was of cross-sectional descriptive research. The population of the study consisted of first and second year students $(n=79)$ from Isparta University of Applied Sciences, Technical Sciences Vocational School, Department of Opticians. The sample consisted of students who voluntarily participated in the study $(n=76)$. A population selection was not made, as it was aimed at reaching the whole potential student population. After the information about the study was transferred to the groups on the mobile application, which is actively used by the students, who are all members, the pre-prepared questionnaire form was shared through Google Docs, internet-based online software. Volunteer students were then asked to fill out the questionnaire for participation in the study. The survey form consisted of 35 questions and three parts: demographic data (5 questions), COVID-19 awareness section (15 questions), and ways of transmission of COVID-19 in the workplace and prevention measures (15 questions). The questions regarding the ways COVID-19 is transmitted and the use of protection measures were in two sub-categories: eyeglass frame trials (practitioner close; $<0.5$ meters, usually short duration; less than 10-20 minutes) and contact lens trials (practitioner at close range; $<0.5$ meters, usually $10-20$ minutes long for long periods).

The SPSS 22.0 package program was used to evaluate the study data. Distribution analysis was used to interpret the data.

\section{Results}

Fifty-one women (67.1\%), 76 students from the optician department, participated in the survey, 19.7\% of the respondents were active employees in an existing workplace. The majority $(76.3 \%)$ of the participants were living at home with three or more others.

In the COVID-19 awareness section, $82.9 \%$ of the participants had information about what COVID-19 is, $19.7 \%$ felt that this infection would not cause conjunctivitis, $32.9 \%$ felt that it could be transmitted from packages from China, and $9.2 \%$ reported that it could be transmitted from pets.

Further, $51.3 \%$ of the respondents stated that they followed the instructions of the Ministry of Health. Of the $64.5 \%$ who knew the Hayat Eve Sigar (HES) application, only $25 \%$ stated that they followed the HES application on their mobile phones (Figure 1). For up-to-date information on COVID-19, 78.9\% (the highest group) reported benefiting from Google and general search engines, and $17.1 \%$ from PubMed (the least group) (Figure 2). In the questions where daily working conditions were evaluated physically, $84.2 \%$ stated that they paid/would pay attention to the ambient ventilation and $86.8 \%$ stated that they paid/would pay attention to the number of customers in the working environment during the pandemic period. 


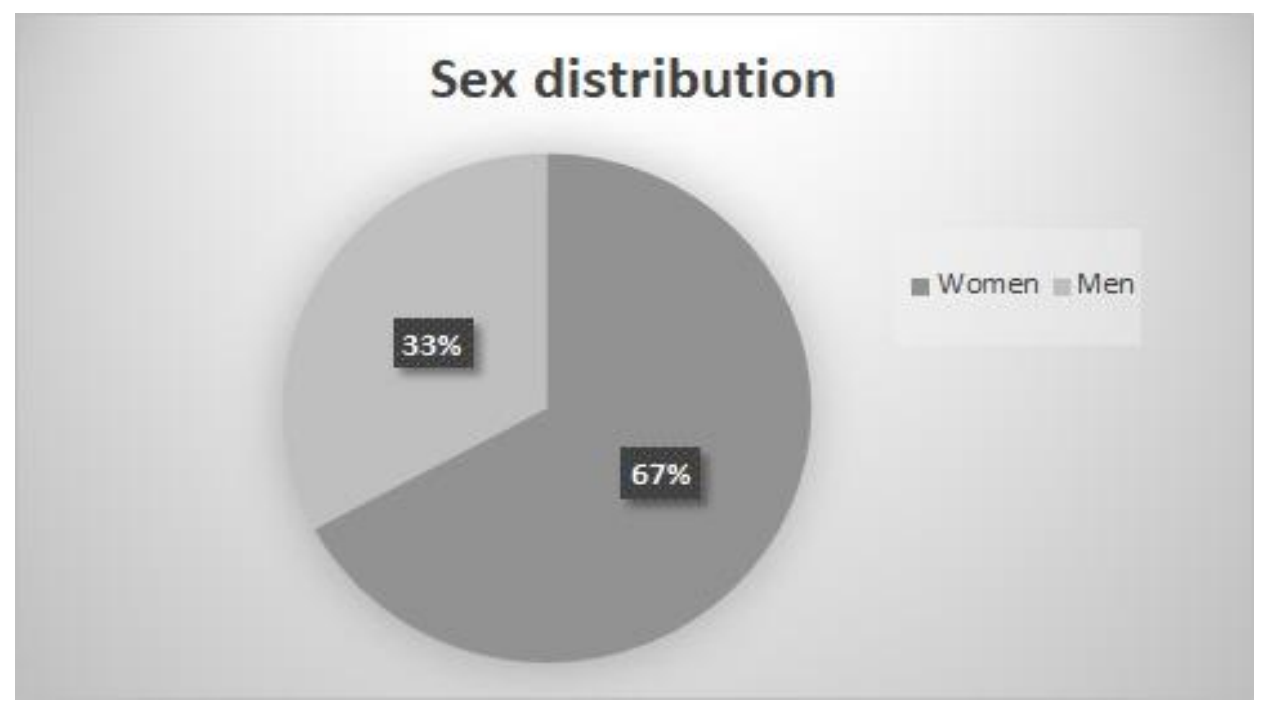

Figure 1: Covid-9 Awareness

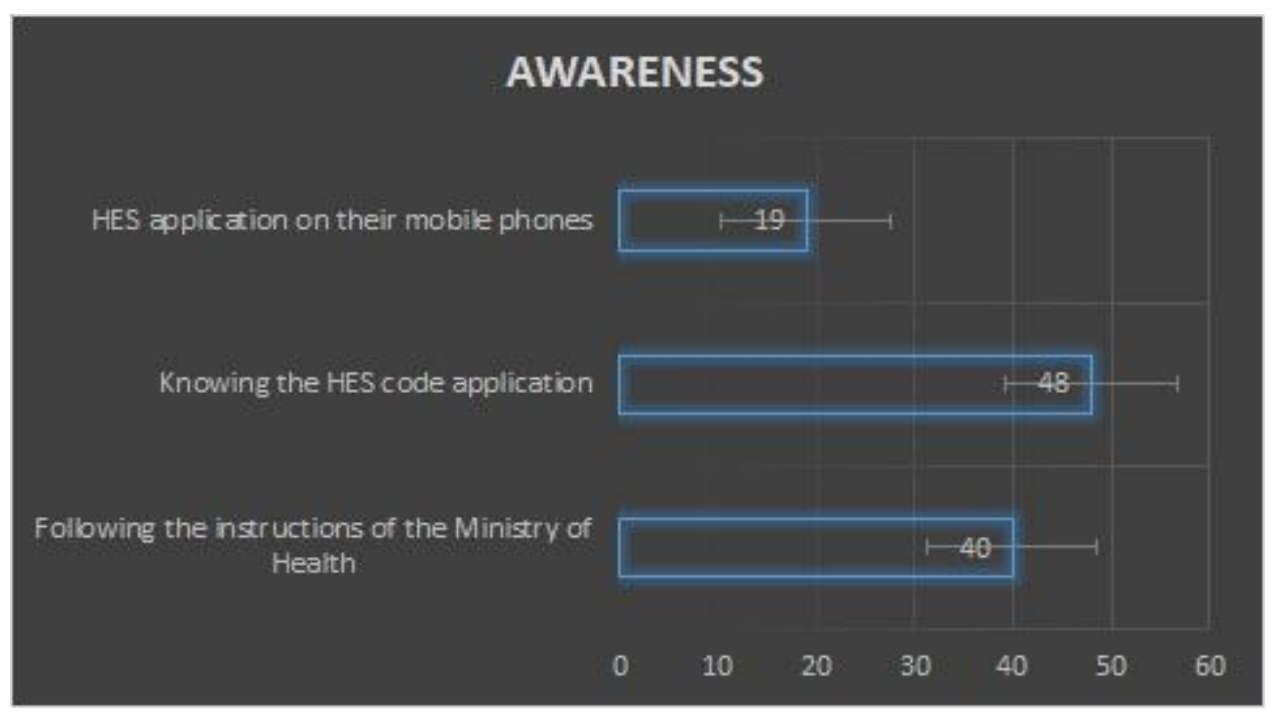

Figure 2: Current information Sources for COVID-19

During the pandemic, $48.7 \%$ of the participants reported that they found eyeglass frame trials inconvenient, and $73.7 \%$ found contact lenses trials inconvenient. Participants found it inconvenient for customers with fever and cough to try on eyeglass frames $(71.1 \%)$ and contact lenses $(81.6 \%)$. In cases where the trial was unavoidable, $96.1 \%$ of the participants stated that their hands should be washed after each contact, and $93.4 \%$ would use a disinfectant for hand hygiene.

While $44.7 \%$ of the participants stated that they would not try on eyeglass frames during the pandemic, $96.1 \%$ of those who stated that they could try with the eyeglasses stated that they would definitely wipe the frames with disinfectant after use. Regarding personal protection equipment, in the eyeglass frame trial, $77.6 \%$ of the participants stated that they would use a mask, $71.1 \%$ gloves, $30.3 \%$ a face shield, and $25 \%$ would use protective glasses (Figure 3 ). While $65.8 \%$ stated that they would not try contact lenses in the same period, $48.7 \%$ of those who stated that they would try contact lenses, had a mask, $51.3 \%$ had gloves, $21.1 \%$ had a face shield, and $13.2 \%$ reported that they would prefer protective glasses as personal protective equipment (Figure 4). When the mask preferences of the participants were evaluated, $69.7 \%$ reported that they would use surgical masks, $26.3 \%$ cloth masks, $17.1 \%$ FFPIII, and $6.6 \%$ reported that they would use FFPII (Figure 5). 


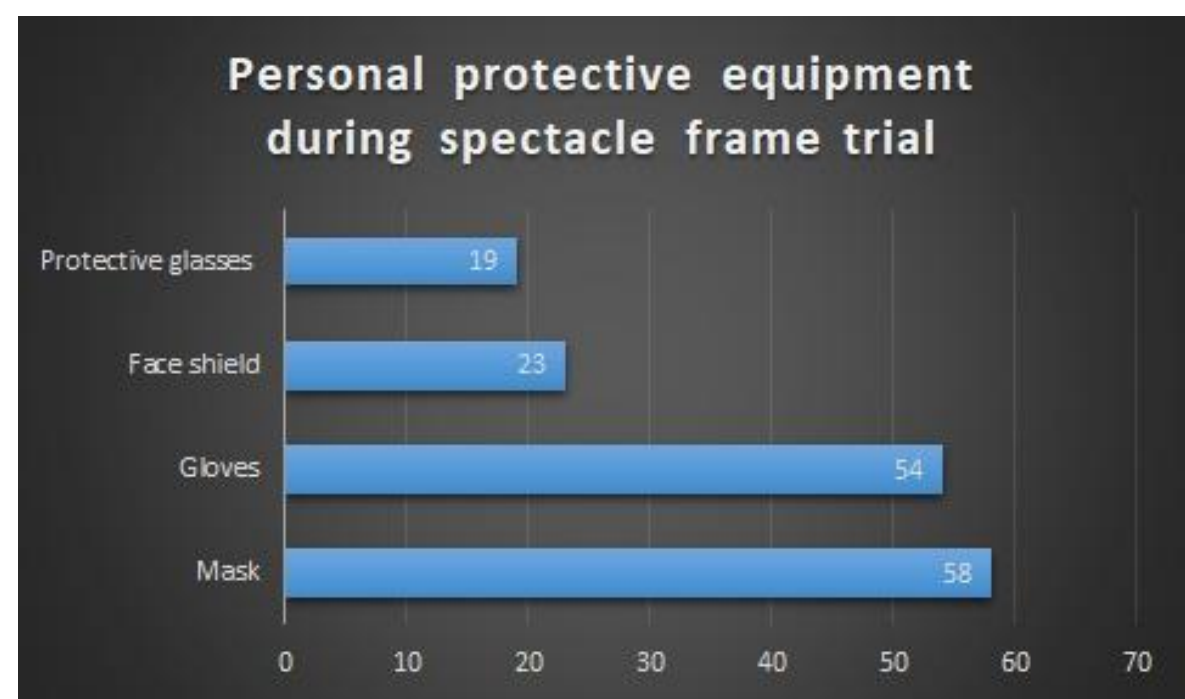

Figure 3: Personal Protective Equipment choice during spectacle frame trial

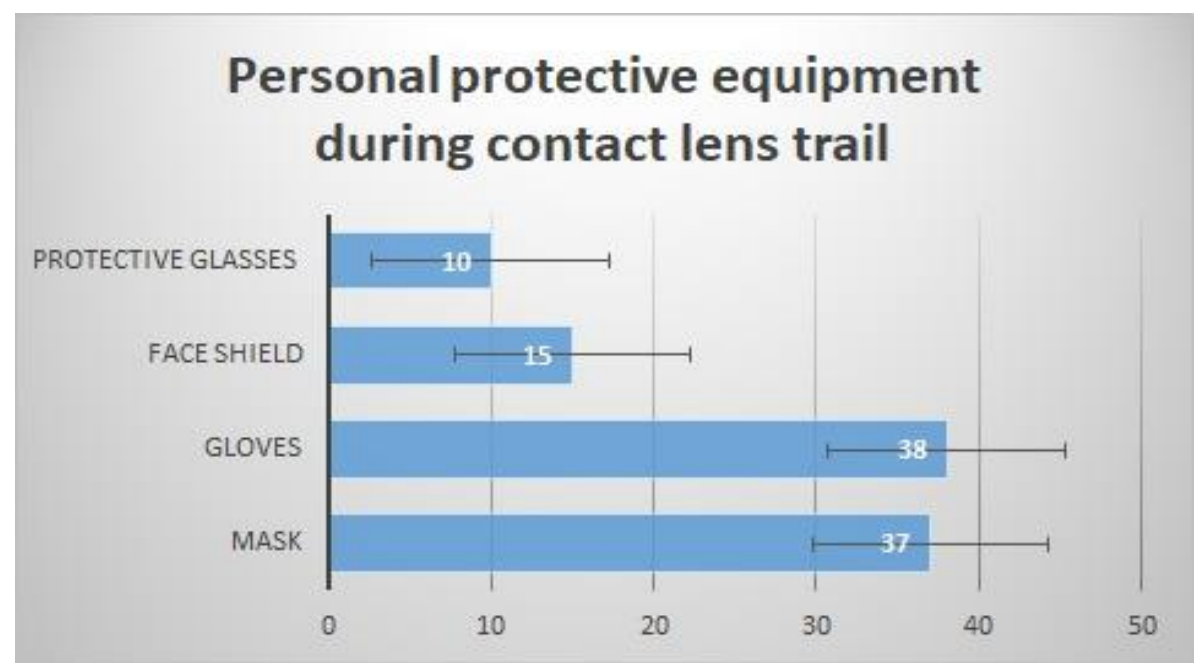

Figure 4: Personal Protective Equipment choice during contact lens trial

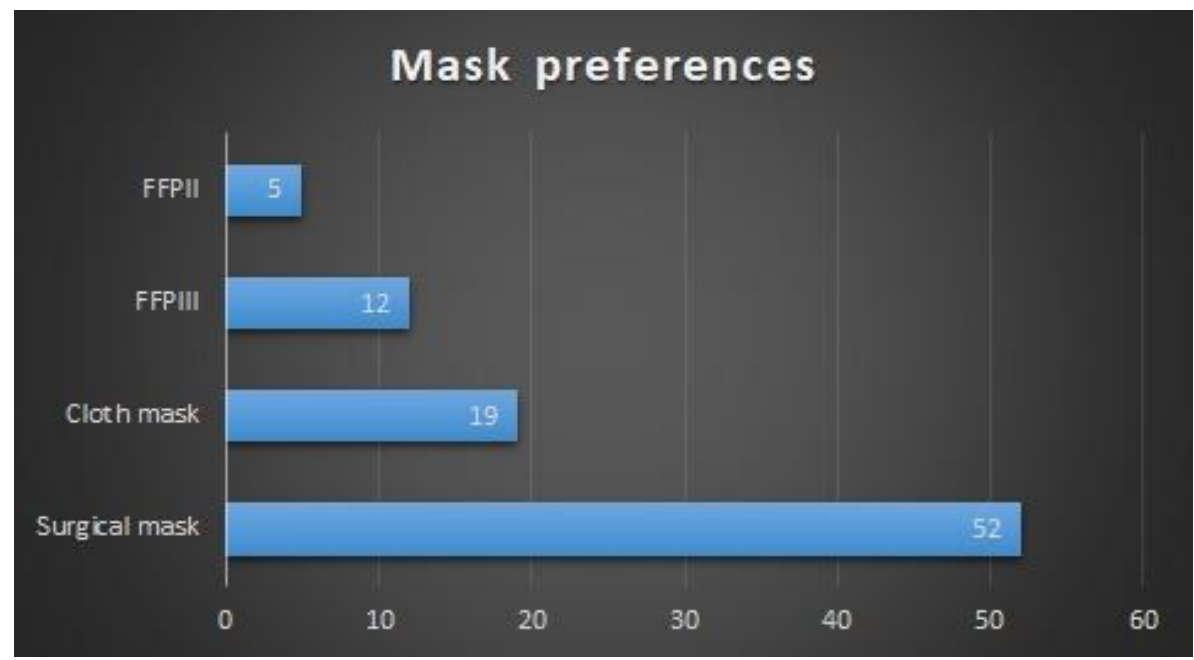

Figure 5: Mask preferences 


\section{Discussion and Conclusion}

With coughing and/or sneezing, it has been shown that the droplets of COVID-19 can travel up to a range of 6 meters, covering the distance between the patient and the optician [7]. It has been stated that the risk of contact with tears, whose contagiousness is emphasized, is high for ophthalmologists and opticians and the instruments used by both professions [5]. The available data in our study revealed concrete information regarding opticians' thoughts on adaptation to the epidemic and on personal protection during the pandemic period.

In the standardization of optician practices, Zentral Verband für Augenoptik und Optometrie (National Optics and Optometry Association, Germany) and the College of Optometrists (Optometrist College, England) associations both emphasized taking detailed anamnesis of the patients, and they reported that all symptomatic COVID-19 patients and potentially infected people should be kept away from these practices [6,9]. In the literature, it is recommended that opticians wash their hands frequently, avoid shaking hands, obey the 1.5-meter distance rule during application, disinfect surfaces, and clean the customers' eyeglasses before repairing or adjusting them [9]. However, wearing gloves or other personal protective equipment during asymptomatic customer contact is not recommended [6]. It has been suggested that, if possible, only disposable gloves and surgical masks should be used [6,9]. In evaluating the data of this study, it was seen that most of the optician students were knowledgeable and conscious about the use of personal protective equipment in accordance with the literature.

Within the data of our study, it was seen that the participants, who are the opticians of the future, tend to follow up-to-date information about the pandemic. In today's world, in line with the continuous development of knowledge, and the rapid progress of science, it can be predicted that these tendencies of students will contribute positively to their professional lives. However, it is important to access accurate and reliable information and to be a lifelong learner, with continuous professional development. It has been reported that, when the quality of the information obtained cannot be determined, that information cannot be used professionally [10]. In one study, it was stated that, although students in the field of health stated that they are equipped to make decisions about the quality of health resources on the internet, they feel that they cannot use the information on the internet safely [11]. Both in line with the literature and in light of our results, it was determined that the participants considered accessing information via the internet and search engines as their first choice. The number who preferred to use scientific databases to reach reliable and accurate information was relatively small. If the tendencies of our students, whom are educated to be life-long learners, are supported with the right educational content, they will reach up-to-date professional information from the appropriate sources, and they will transfer this information to their professional lives with confidence.

Due to the small sample size available, the limitation of our study can be considered as a limited representation of the general population. Moreover, because the majority of our survey participants were students, there may be deficiencies in the awareness of the difficulties that they may encounter in their professional lives.

Drawing attention to standard personal protective equipment protocols against COVID-19 infection and determining the level of awareness regarding the ways the virus is transmitted, especially in students who will work in the health field, can be considered as the most important contribution of this article to the literature. It is particularly important for optician students, who provide or will serve in the health field, to access up-to-date information about transmission and prevention methods. For this, if necessary, training will increase the knowledge and awareness regarding COVID-19 and it will provide serious benefits in the fight against the virus.

\section{References}

[1] News B. China Will Rack Up Three Billion Trips During World's Biggest Human Migration 2020 [https://www.bloombergquint.com/global-economics/china-readies-for-world-s-biggest-human-migrationquicktake-2].

[2] Huang C, Wang Y, Li X, Ren L, Zhao J, Hu Y, et al. Clinical features of patients infected with 2019 novel coronavirus in Wuhan, China. Lancet. 2020;395(10223):497-506. 
[3] van Doremalen N, Bushmaker T, Morris DH, Holbrook MG, Gamble A, Williamson BN, et al. Aerosol and surface stability of HCoV-19 (SARS-CoV-2) compared to SARS-CoV-1. medRxiv. 2020.

[4] Zhou M, Zhang X, Qu J. Coronavirus disease 2019 (COVID-19): a clinical update. Front Med. 2020;14(2):12635.

[5] Minocha A, Sim SY, Than J, Vakros G. Survey of ophthalmology practitioners in A\&E on current COVID-19 guidance at three Major UK Eye Hospitals. Eye (Lond). 2020;34(7):1243-5.

[6] Pult H. COVID-19 Pandemic: Survey of future use of personal protective equipment in optometric practice. Cont Lens Anterior Eye. 2020;43(3):208-10.

[7] Romano MR, Montericcio A, Montalbano C, Raimondi R, Allegrini D, Ricciardelli G, et al. Facing COVID-19 in Ophthalmology Department. Curr Eye Res. 2020;45(6):653-8.

[8] The College of Optometrists. Coronavirus ( COVID-19) pandemic: Guidance for optometrists. 2020 [https://www.college-optometrists.org/guidance/covid-19-coronavirus-guidance-information/covid--collegeguidance/primary-eye-care-covid--pandemic-guidance.html].

[9] Turakhia S, Saoji Y, Goyal A, Chande P, Hussaindeen JR, Konda N, et al. COVID-19 guidelines for optometry and optical services post-lockdown. Indian J Ophthalmol. 2020;68(8):1533-9.

[10] Watkins I, Xie B. eHealth literacy interventions for older adults: a systematic review of the literature. J Med Internet Res. 2014;16(11):e225.

[11] Yılmaz A, Saygılı M, Kaya M. Sağlık Bilimleri Fakültesi Öğrencilerinin E-Sağlık Okuryazarlığı Düzeylerinin Belirlenmesi. Mehmet Akif Ersoy Üniversitesi Sosyal Bilimler Enstitüsü Dergisi. 2020;31:148-57. 